\title{
Examining the Linkage between Poverty and Macroeconomic Variables in Malaysia: A Co-integration Analysis
}

\author{
Gurmit Kaur, Siti Ayu Jalil ${ }^{*}$ \\ Universiti Teknologi MARA (UiTM) Puncak Alam, Selangor, Malaysia \\ gurmit601@salam.uitm.edu.my, *sitiayujalil@yahoo.com
}

\begin{abstract}
The purpose of this paper is to examine the linkage between the macroeconomic variables i.e. gross domestic product per capita (GDP), unemployment (UNE), tourist receipts (TOU), consumer price index (CPI) and poverty rate (POV) in Malaysia from 1969-2014. The econometric techniques used are unit root test and the Johansen Cointegration. The Granger Causality test using Block Exogeneity Wald test was added to analyze the causal relationships between the variables. The unit root test showed that all variables were stationary at first difference and thus the Johansen Co-integration test is an appropriate technique to employ. The evidence from co-integration test indicates that all the five series have three (3) co-integrating equations and significance at 1 percent level of significance. The causality test indicated there is a significant unidirectional causality between POV on GDP, CPI on POV, POV on TOU, GDP on UNE, GDP on TOU and CPI on TOU and bidirectional causality between POV and UNE. This paper is possibly the first to discuss these relationships in Malaysian context using Co-integration analysis. The finding implies that poverty is the key issue that should be addressed to achieve a high-income country status in the year 2020 .
\end{abstract}

Keywords: Poverty; Macroeconomic variables; Unit Root test; Johansen Cointegration test; Granger Causality test

\section{Introduction}

Malaysia's economy is highly open and in the upper middle-income group advancing towards high- income status by 2020. It has developed from an agriculture-dominated economy in the 70s to a manufacturing based economy in the $21^{\text {st }}$ century. The economy has successfully maintained a growth rate of $6 \%$ per year for the past 60 years (Budget, 2017). However, with this vision and success the main concern, which is also a universal issue, is poverty. Poverty is an unacceptable human condition and a major social problem in this century. Poverty in Malaysia has reduced tremendously over the years, but there remain stubborn pockets of poverty that elude current policy measures and new forms of poverty are emerging which becomes a challenging issue to achieve a high- income status (Nair \& Sagaran, 2015). Poverty is a proof of inequality and a reflection of government performance (Affandi \& Astuti, 2014). According to Nair \& Sagaran (2015) the current policy measures to address poverty are inadequate and what is required is an actual plan to address real poverty. Generally, there are two different types of strategies that can be adopted to manage poverty. The first strategy is to target the poor directly by breaking the vicious circle of poverty. The other strategy is to formulate policies which would augment the macroeconomic variables that have linkages with poverty (Chani, Pervaiz, Jan, Ali \& Chaudhary, 2011). This paper analyses the long-run linkage between poverty and macroeconomic variables: economic growth, unemployment, inflation and tourism in Malaysia. By having established the relationship between these variables the government can formulate policies to alleviate poverty.

In Malaysia, poverty line depends on which region the household's lives, Peninsular Malaysia, Sabah or Sarawak. The average household monthly income of the poor in Peninsular is below RM760, Sabah is RM1050 and Sarawak is RM910. This average monthly income for the poor is computed based on the income level "deemed" necessary to maintain a certain standard of consumption. Extreme poverty is based on the amount necessary to fulfill basic needs that is a household earning less RM460 in Peninsular Malaysia, RM630 in Sabah and RM590 in Sarawak. The vulnerable group, on the other hand, is households with an income of less than RM2000 per month (Jala, 2015). There are 56,557 households who are poor, 44,643 hard-core poor and 83,364 in the vulnerable category. The problems of poverty are said to be complex and multidimensional. The poor have limited access to basic necessities, are exposed to exploitation and vulnerable to the environment (Zainal, Kaur, Ahmad, \& Khalili, 2012). Poverty undermines the quality of life for everyone in the economy. As there is a "hidden cost" of poverty that is, deteriorating value of real estate 
and increasing the expenditure for law enforcement, reformative and health care centers, which is borne by everyone. Therefore, the implication of poverty is not only on the poor, but also on the population at large.

Malaysia has been experiencing a notable growth over the last few decades as it is well-endowed with natural resources and established infrastructure. Malaysia's Vision of 2020 of being a high-income nation began with the advent of the New Economic Policy (NEP) from the year 1970 to 1990, followed by the National Development Plan (NDP) from the year 1991 to 2000, then the National Vision Policy (NVP) from the year 2001 to 2010 and finally New Economic Model (NEM) from the year 2010 to 2020. The NEP had a twopronged strategy of eradicating poverty and restructuring the economy and NDP incorporated Economic Imbalance, followed by NVP building a resilient and competitive nation and finally NEM achieving highincome nation status. The success of this policy was seen through the reduction in poverty, unemployment, and increase in per capita income. This study includes tourism because the tourism sector is the $2^{\text {nd }}$ largest foreign exchange earner in Malaysia and the $6^{\text {th }}$ largest contributor to gross domestic product. Tourism in the context of Malaysia is the most important sector as it has top tourism destination with respect to national parks, wilderness areas and cultural diversity. Pro-poor tourism was put on the agenda in 1999. Even though it is relatively a new phenomenon, some elements can be observed in tourism development. The impact of tourism can be seen with respect to its contribution to GDP (14.9\%), employment (13\%) and investment (6.8\%). According to WTTC (2014) tourism contribution will increase in the future. According to Croes (2014), developing countries are focusing on tourism activity to reduce poverty.

This study examines the linkage between poverty and selected macroeconomic variables: economic growth, unemployment, consumer price index, and tourism receipts. The link between macroeconomic variables and poverty is complex and has not been fully investigated in the context of Malaysia. As Malaysia is formulating aggressive macroeconomic policies to accomplish the high-income country status by 2020 , it is crucial to examine this linkage. Previous studies on poverty concentrated mostly on microeconomics, however, it has been recognized that macroeconomic variables have an influence on poverty. This study investigates this linkage in Malaysian context using cointegration analysis. This paper examines the long-run relationship between poverty rates and macroeconomic variables.

\section{Literature Review}

This section presents some literature on poverty and between poverty and selected macroeconomic variables.

Poverty: The World Development Report 1990 constructed two indices based on consumption level and standard of living. The first is based on the amount of income necessary to provide for basic needs such as food, clothing and shelter. It is country-specific and is defined as absolute poverty. Poverty is related to failed income "dollar a day". The second is relative poverty which is based on the situation of the individual within the social structure (Gascón, 2014) and is assessed against the variation in the standard of living (Iceland, 2005). Most studies used headcount ratio based on the standard measure of poverty (Akhtar, Hunjra, Safwan, \& Ahmad, 2012) as the data is easily available and easy to understand (Tyler, El-Ghonemy \& Couvreur, 1993). However, some studies have used alternative measures as the official poverty baseline threshold is considered low. Defina (2002) used revised headcount rate where the poor are identified using a higher poverty threshold approved by a Panel on Poverty and Family Assistance and Powers (1995) used consumption poverty measure. Poverty in Malaysia is measured in the absolute term that is the percentage of poor households to the total population. The Poverty Line Index is determine by the minimum consumption required by an average size household for food, clothing, shelter and other non-food needs such as fuel, transport and education (Nations, 2015). Studies in Malaysia normally use this poverty line to measure poverty (Ahmed, 2014; Hatta \& Ali, 2013).

Poverty and Economic growth: Economic growth is said to be an influential instrument to reduce poverty and most extensively studied. The rate at which poverty reduces when income increases is said to be different and depend on various factors. From the macroeconomics perspective, the extent to which economic growth affects the poverty reduction depend on the distribution effect of economic policy (Ravallion, 1997). A study was done by Amini \& Dal Bianco (2016) using the GMM estimator found the poverty elasticity to 
growth is $-2 \%$, however, the relationship is more favorable at the lower initial level of poverty and inequality compared to higher levels at both $\$ 1.25$ and $\$ 2$ poverty line. Studies using different methodology specification found a significant negative relationship between growth and poverty and proposed strategies to reduce poverty. Afzal, Malik, Begum, Sarwar, \& Fatima (2012) used time series data and applied ARDL Model for Pakistan revealed that there is a significantly inverse relationship between poverty and economic growth in the long-run. Using Toda-Yamamoto Augmented Granger Causality (TYAGC) Test they concluded a bi-directional causality between these variables. The study also suggested that pro-poor growth strategies can be adopted to reduce poverty. Another study was done in Pakistan by Tahir, Perveen, Ismail, \& Sabir (2014) using OLS suggested the low pace of growth in Pakistan has to be addressed by job creation and employment opportunities to reduce poverty. Belke and Wernet (2015) using the GMM estimator for 59 developing countries concluded that investment induces growth rate whereas population growth increases poverty. On the contrary,Page \& Shimeles (2015) in their study in Africa found that in spite of solid growth in per capita GDP poverty reduction was minimal with an income elasticity of 0.95 . The weak link was caused by the lack of structural changes and aid was given to support education and health but not for job creation. Studies were also conducted to investigate the relationship between poverty and different measurement of economic growth. Vanegas (2014), measured economic growth based on per capita GDP and by disaggregating growth into economic sector components using unbalance panel data revealed the relationship between poverty, inequality and economic growth varied relatively very slight between these different measures and the coefficients are highly significant with expected signs.

Poverty and Tourism: In the 1990s, the relationship between tourism and poverty reduction gave rise to pro-poor tourism (PPT) strategies. PPT uses tourism as a tool to increase the net income of the poor. Kakwani \& Pernia (2000) defines pro-poor tourism as tourism related activities that can assist the poor to participate actively in and also significantly benefit from economic activity. PPT can be applied to micro and macro level of development (Ashley \& Mitchell, 2007). Benefits from tourism are multifold. Benefits from tourism are direct when tourists purchase goods and services, benefiting the business owners and labor. Indirect benefits arise from purchases of inputs and inter-sectoral linkages among firms to boost the tourism industry. Long-term benefits arise from tourism as it will promote larger investment in infrastructure, employment and other economic activities. World Tourism Organization promotes the view that states "the power of tourism - one of the most dynamic economic activities of our time - can be more effectively harnessed to address the problems of poverty more directly" (WTO, 2002: 17). A study done by Croes \& Vanegas (2008) revealed a long-run relationship between tourism, economic growth and poverty reduction. According to Carbone (2005) developing tourism sector is favourable to pro-poor growth because of the multiplier effects and the opportunities the informal sector provide for female and unskilled labor. However, some studies revealed that tourism increases net income at the expense on inequality. Gascón (2014) revealed that tourism created a new elite group that gained from tourism and the remainder improvised as they lost access to some resources. Saayman, Rossouw, \& Krugell (2012) in their study on South Africa concluded that tourism income did not trickle down to the poor and deliberate actions are needed to use tourism receipt to help the poor.

Poverty and Unemployment: The relationship between poverty and unemployment is unique as the poor has only one asset that is labour. Their main source of income is through the labour market. The unemployed tend to have the highest risk of experiencing poverty. A study done by Defina \& Thanawala (2009) explored the impact of unemployment and inequality on Canadian poverty using province-panel data from 1980-1998 for both overall population and selected sub-group. The study concluded that unemployment and inequality have a significant effect on overall poverty. Studies have investigated different poverty measures to examine this linkage. Research done by Defina (2002) revealed that revised poverty headcount rate has a much weaker relationship compared to the official headcount poverty rate. Akinbobola \& Saibu (2004) used the human capital index to measure poverty found that when public expenditure increases unemployment decrease and the human capital index improves.

Poverty and Inflation: The consumer price index is used to measure inflation rate. Inflation tends to hurt the poor more than the rich, as the rich has access to financial instruments compared to the poor who tend to hold cash in their portfolio. Easterly \& Fischer (2001) study in 38 countries found that high inflation lowers 
the share of the bottom quintile. Son \& Kakwani (2008) findings captured the price elasticity of poverty with respect to headcount as $1.44 \%$, poverty gap ratio as $1.77 \%$ and severity of poverty as $2.01 \%$.

Poverty and Macroeconomic Variables: Studies have incorporated selected macroeconomic variable in their study on poverty to predict the relationship and for policy making. Vijayakumar (2013) used OLS to study the relationship between poverty, GDP growth, dependency ratio and employment with respect to industrial employment and agriculture employment in 41 developing countries. The study found that age dependency ratio and economic growth significantly affects poverty. Kashi \& Tash (2014) explored using the bootstrap technique found that economic growth is negatively related to poverty whereas unemployment rate and inflation is positively related. Sabir \& Tahir (2012) investigated the association between GDP growth, inflation, on poverty in Pakistan. The study concluded that in the long run poverty reduction is driven by changes in macroeconomic variables. Chani et al. (2011) in their study "Poverty, inflation and economic growth: empirical evidence from Pakistan" examined the relationship between the economic growth, inflation and poverty using ARDL over the period of 1972-2008. The study revealed a long run relationship between economic growth and inflation. Their result also concluded that inflation, economic growth and investment have the expected signs. The short run analysis showed that economic growth and inflation has a negative and positive impact respectivly on poverty. Akhtar, et al., (2012) using cointegration found that CPI, literacy rate and population growth have a significant long-run relationship with poverty in Pakistan. Powers (1995) examined the association between inflation, unemployment and poverty. His findings revealed that unemployment and poverty are positively related to both poverty rates that is conventional and JS poverty, whereas inflation has a large positive influence only on JS poverty rate.

\section{Empirical modeling}

Econometric analysis: This section will discuss the econometric techniques employed to examine the relationship between the macroeconomic variables and poverty rate. The techniques used are Johansen Cointegration test and the Granger Causality test. However, before applying the appropriate time-series econometric technique, the unit root test is crucial to determine the stationary status of data using the Augmented Dickey Fuller (ADF) and Phillips-Perron (PP) tests. The economic model starts with the function as:

Where POV =poverty rate

GDP =economic growth

UNE =unemployment rate

TOU =tourism receipts

CPI =consumer price index

$$
P O V=f(G D P, U N E, T O U, C P I)
$$

Basically, the econometric modeling would be:

$$
\ln P O V_{t}=\beta_{0}+\beta_{I} \ln G D P_{t}+\beta_{2} \ln U N E_{t}+\beta_{3} \ln T O U_{t}+\beta_{4} \ln C P I_{t}+\varepsilon_{t}
$$

Where $\beta_{0}$ is constant; $\beta_{1}, \beta_{3}<0$ and $\beta_{2}, \beta_{4}>0$

$\ln \quad=$ logarithm

$t \quad=$ time-period from 1969-2014

$\varepsilon \quad=$ error term

The first part of the analysis will test the existence of unit root shown by the equation:

$$
\Delta Y_{t}=\beta_{0}+\beta_{I} T+\beta_{2} Y_{t-1}+\sum_{j=1} \Psi_{j}^{p} \Delta Y_{t-j}+\varepsilon_{t}
$$

Where $\Delta$ refers to the change in $Y$ and $Y$ is the natural logarithm of the five variables (POV, GDP, UNE, TOU and CPI), $\beta_{0}$ is constant while T is the trend variable. Parameters $\beta$ and $\Psi$ are estimated, and $\varepsilon$ denotes the error term. When the variables integrated order is identified, the appropriate model is set up. Since all the variables were integrated at order I (1), it suggests that the series will converge to a long run equilibrium over time. In 
other words, theoretically, when a cointegration relationship exists, it means the dependent and independent variables will share a common trend. Thus, the chosen appropriate technique employed would be Johansen and Juselius test which is based on trace statistics. The equation is stated as:

$$
\begin{aligned}
& \Delta y_{t}=\mu+\Pi y_{t-1}+\sum_{i=1}^{p-1} \Gamma_{i} \Delta y_{t-i}+\varepsilon_{t} \\
& \text { Where } \Pi=\sum_{i=1}^{p} A_{\mathrm{i}}-\mathrm{I} \text { and } \Gamma_{i}=-\sum_{j=i+1}^{p} \mathrm{~A}_{\mathrm{j}}
\end{aligned}
$$

$y_{t}$ is the vector of variables i.e. poverty rate, GDP, unemployment, tourism and CPI that are integrated of order one, I(1). The number of cointegration vectors, $r$, is determined by the maximum eigenvalue test and the trace test using the likelihood ratio test. If the maximum eigenvalue test and trace test were conflicting, the chosen number of the cointegration vector should be based on the former, since the test has a better alternative hypothesis. The cointegration test may explain the long run relationship among these variables; however, the test would not indicate the direction of their causal relationship. Hence, the Granger Causality applying the Block Exogeneity Wald test was added to indicate their short run causality relationship among them. The test statistic is shown as:

$$
(T-3 p-1)\left(\log \left|\Sigma_{r e}\right|-\log \left|\Sigma_{u n}\right|\right) \sim \chi^{2}(2 p)
$$

Where $T$ is the time period, $\Sigma_{u n}$ is variance of the unrestricted VAR system while $\Sigma_{r e}$ is variance of the restricted system when the lag variable is excluded from the system; and $p$ refers to the number of lags. When the null hypothesis is rejected, it means that in this case if all lags of GDP cannot be excluded from the POV equation, POV is said to be an endogenous variable and thus causal relationship runs from GDP to POV. However, this test statistic may not explain the strength of the impact of each variable.

Definition of variables and Data sources: Organization for Economic Cooperation and Development (OECD) defines poverty rate as the ratio of the number of people below the poverty line and the total population. The poverty line is defined as half the median household income. In Malaysia, a household is considered poor if and only when their monthly income is below Poverty Line Income (PLI) that is US\$8.50 per day in 2012 (Jala, 2015). GDP per capita is computed by dividing the gross domestic product by midyear population measured in constant U.S dollars. The unemployment rate measures the percentage of labor that is both jobless and is looking for a job, which is in accordance with International Labor Organization (ILO). Tourism annual receipt is measured in RM billion and defined as an activity of travelling to a place for pleasure. The consumer price index reflects the weighted average price of a basket of goods and services such as food, transportation, clothes, and medical care of the country. Data of each variable spanning from 1969 to 2014 are gathered annually for 46 years. These time-series data are obtained from different reliable sources. The data on poverty was gathered from the Economic Planning Unit website of Malaysia. Whereas data on GDP per capita and consumer price index was extracted from World Development Indicators. The data on unemployment rate from was gathered from Malaysian Economic Report from year 1969 to 2014. Tourism receipt data was gathered from World Travel \& Tourism Council and Tourism Malaysia website.

\section{Findings}

The findings begin with the descriptive analysis of each variable as shown in Table 1. Basically, the table displays the characteristics of each series of variables from 1969-2014. Starting with POV, it has the mean of 18.189 and the standard deviation of 15.309 followed by GDP with a mean of 5422.098 and standard deviation of 2550.783. UNE has the mean and the standard deviation of 4.826 and 2.083 respectively. Next is TOU, the mean and standard deviation scores of 17.549 and 20.685 respectively, and, last CPI with mean of 63.498 and standard deviation of 25.974. The data reveals a reasonable goodness-fit measure based on their skewness of the series which is close to zero. On the other hand, the height of the distribution relative to a normal distribution measured by Kurtosis depicts a normal distribution since the values of the series have a uniform distribution of about 3. 
Table 1: Descriptive statistics

\begin{tabular}{llllll}
\hline & POV & GDP & UNE & TOU & CPI \\
\hline Mean & 18.189 & 5422.098 & 4.826 & 17.549 & 63.498 \\
Median & 13.530 & 4934.950 & 3.750 & 7.095 & 60.660 \\
Std. deviation & 15.309 & 2550.783 & 2.083 & 20.685 & 25.974 \\
Skewness & 0.737 & 0.339 & 0.957 & 1.333 & 0.107 \\
Kurtosis & 2.232 & 1.8548 & 2.498 & 3.356 & 1.870 \\
Jarque-Bera & 5.292 & 3.397 & 7.504 & 13.870 & 2.533 \\
Probability & 0.071 & 0.183 & 0.023 & 0.001 & 0.282 \\
\hline
\end{tabular}

The first step of the analysis was to run the unit root test using the ADF and PP tests for the five variables with constant and time trend, and the results are reported in Table 2. The results reveal that the unit root test is not stationary at their levels i.e. I(0). When applying the first order-differencing I(1), all the variables become stationary at $1 \%$ level of significance. Therefore the results evidently proved that the null hypothesis of the presence of unit root is rejected, implying that the variables can cointegrate.The next step is to proceed with the testing for the presence of a common trend, or equivalently, a long run co-integrating relationship between the variables. Since the Johansen cointegration method needs to identify the lag length used, a series of nested likelihood ratio tests is utilized to determine the optimum lag length. A maximum lag length of six has been chosen based on the sample size of the series. The optimal lag length is given as five and this lag is utilized throughout the estimations. Tables $3 \mathrm{a}$ and $3 \mathrm{~b}$ reveal the evidence of performing the Johansen cointegration tests using the software e-views 9. The trace and maximum eigenvalue statistics will determine the existence of the long-run equilibrium relationship among the variables. Table 3a reports the trace test, while Table 3b reports the maximum eigenvalue test. Each column (1) until (5) report the number of cointegrating vectors, the eigenvalue, the trace statistic or maximum-eigen statistic that equal to each number of co-integrating vectors, the critical value at 5\% significance level and the $p$-value, respectively. The hypothesis to consider is that the variables are not cointegrated $(r=0)$ against the alternative of one or more cointegrating vectors $(r>0)$.

Table 2: Unit root test

\begin{tabular}{lllll}
\hline Variables & Unit root based on level & \multicolumn{2}{l}{ Unit root based on first difference } \\
& I(0) & I(1) & PP \\
& ADF & PP & ADF & -7.173 \\
& -0.949 & -0.348 & -7.178 & $(0.000)$ \\
SOV & $(0.941)$ & $(0.987)$ & $(0.000)$ & -5.857 \\
& -1.996 & -2.093 & -5.857 & $(0.000)$ \\
UNP & $(0.588)$ & $(0.535)$ & $(0.000)$ & -4.746 \\
& -2.608 & -2.314 & -4.746 & $(0.000)$ \\
TOU & $(0.279)$ & $(0.418)$ & $(0.000)$ & -5.960 \\
& 0.998 & 0.982 & -5.980 & $(0.000)$ \\
CPI & $(0.999)$ & $(0.999)$ & $(0.000)$ & -5.149 \\
& -1.814 & -2.176 & -5.147 & $(0.001)$ \\
\hline
\end{tabular}

Referring to the third column of Table 3a, the trace statistic values are 223.175, 117.371, 47.493, 11.252 and 0.002 , respectively. Since the value of trace statistic at most 2 i.e. 47.493 exceeds the critical value (29.797) at the $5 \%$ significance level, the null hypothesis of two cointegrating vectors $(\mathrm{r}=2)$ can be rejected. In other words, the results show that there are more than two cointegrating vectors $(r>2)$. On the other hand, since the value of trace statistic at most 3 stated 11.252 is less than the critical value (15.495) at $5 \%$ significance level, one cannot reject the null hypothesis of $r \leq 3$. 
Table 3a: Johansen co-integration test based on Trace Statistic

\begin{tabular}{lllll}
\hline Hypothesized No. of CE(s) & Eigenvalue & $\begin{array}{l}\text { Trace } \\
\text { Statistic }\end{array}$ & $\begin{array}{l}\mathbf{0 . 0 5} \\
\text { Critical Value }\end{array}$ & Probability** \\
(1) & $\mathbf{( 2 )}$ & $\mathbf{( 3 )}$ & $\mathbf{( 4 )}$ & $\mathbf{( 5 )}$ \\
\hline None* $_{\text {At most 1* }}^{*}$ & 0.929 & 223.175 & 69.819 & 0.000 \\
At most 2* & 0.826 & 117.371 & 47.856 & 0.000 \\
At most 3 & 0.596 & 47.493 & 29.797 & 0.002 \\
\hline
\end{tabular}

Trace test indicates 3 cointegrating eqn(s) at the 0.05 level

* denotes rejection of the hypothesis at the 0.05 level

**MacKinnon-Haug-Michelis (1999) p-values

Table 3b: Johansen co-integration test based on Maximum Eigenvalue Statistic

\begin{tabular}{|c|c|c|c|c|}
\hline $\begin{array}{l}\text { Hypothesized No. of CE(s) } \\
\text { (1) }\end{array}$ & $\begin{array}{l}\text { Eigenvalue } \\
\text { (2) }\end{array}$ & $\begin{array}{l}\text { Max-Eigen } \\
\text { Statistic } \\
\text { (3) }\end{array}$ & $\begin{array}{l}0.05 \\
\text { Critical } \\
\text { Value } \\
(4)\end{array}$ & $\begin{array}{l}\text { Probability** } \\
\text { (5) }\end{array}$ \\
\hline None* & 0.929 & 105.804 & 33.877 & 0.000 \\
\hline At most $1^{*}$ & 0.826 & 69.878 & 27.584 & 0.000 \\
\hline At most $2^{*}$ & 0.596 & 36.242 & 21.132 & 0.002 \\
\hline At most 3 & 0.245 & 11.249 & 14.265 & 0.142 \\
\hline
\end{tabular}

Max-eigenvalue test indicates 3 cointegrating eqn(s) at the 0.05 level

$*$ denotes rejection of the hypothesis at the 0.05 level

**MacKinnon-Haug-Michelis (1999) p-values

Similarly, Table 3b shows that the Maximum Eigenvalues statistic of 105.804, 69.878, 36.242, 11.249 and 0.002 , respectively. The test of the null hypothesis $r=3$ against the specific alternative $r=4$ cannot be rejected at 5\% level of significance because the Maximum Eigenvalue at most 3 stated 11.249 is less than 14.265. This unanimously suggests that the number of cointegration vectors is three (3). The result indicates that the five series POV, GDP, UNE, TOU and CPI have three (3) co-integrating equations. The evidence of cointegration only implies the existence of causality at least in one direction but there is no indication of the direction of the causal relationship. Hence, the next step is to conduct the Granger Causality test using the Block Exogenity Wald test to test the null hypothesis of non-causality between poverty and each of the variables. Table 4 presents the results of the direction of causality between POV and the four macroeconomic variables.

Table 4: Granger causality test using the Block Exogenity Wald test

Dependent Variable: LNPOV

\begin{tabular}{|c|c|c|c|}
\hline Excluded & Chi-square & $\mathrm{df}$ & Probability \\
\hline LNGDP & 2.807 & 4 & 0.591 \\
\hline LNUNE & 10.566 & 4 & 0.032 \\
\hline LNTOU & 2.148 & 4 & 0.709 \\
\hline LNCPI & 14.567 & 4 & 0.006 \\
\hline ALL & 12.333 & 16 & 0.721 \\
\hline \multicolumn{4}{|c|}{ Dependent Variable: LNGDP } \\
\hline Excluded & Chi-square & $\mathrm{df}$ & Probability \\
\hline LNPOV & 10.566 & 4 & 0.032 \\
\hline LNUNE & 5.942 & 4 & 0.204 \\
\hline LNTOU & 6.564 & 4 & 0.161 \\
\hline LNCPI & 2.960 & 4 & 0.565 \\
\hline ALL & 24.208 & 16 & 0.085 \\
\hline \multicolumn{4}{|c|}{ Dependent Variable: LNUNE } \\
\hline Excluded & Chi-square & $\mathrm{df}$ & Probability \\
\hline LNPOV & 14.567 & 4 & 0.006 \\
\hline
\end{tabular}




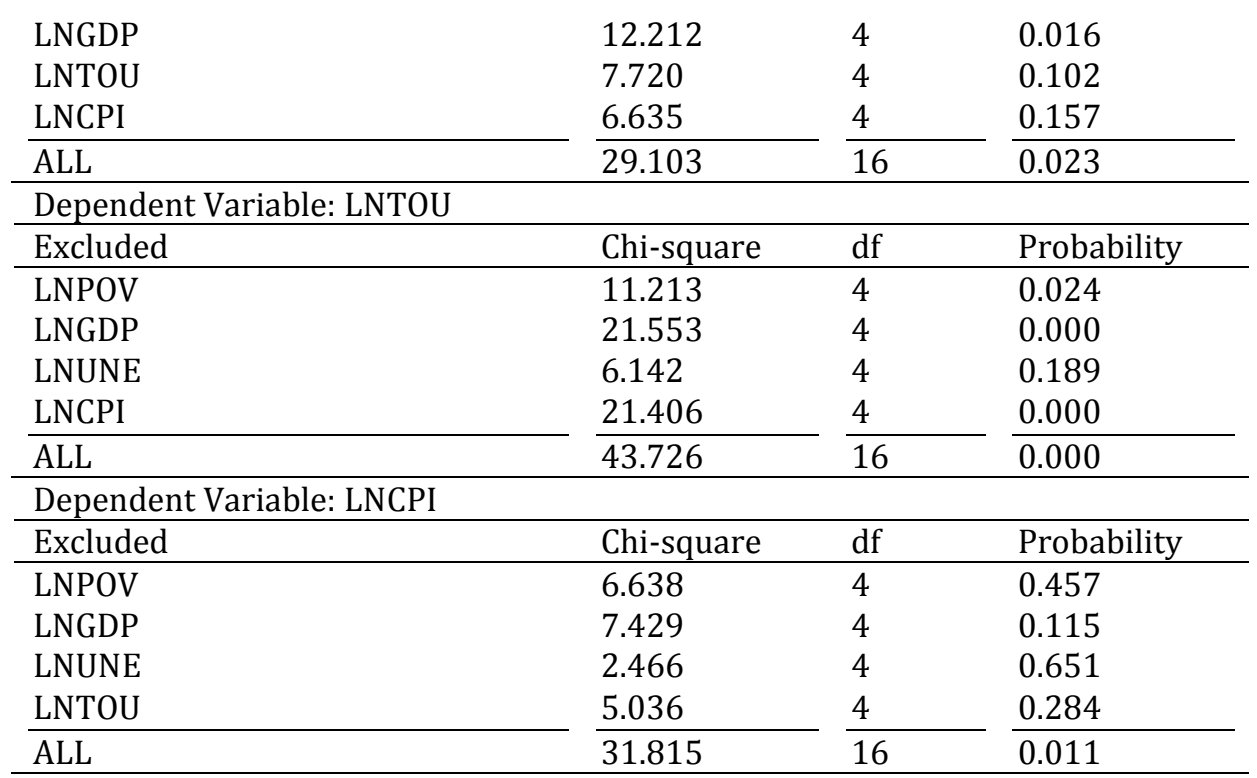

Table 4 consists of four columns which begin with the stated macroeconomic variables (column 1) followed by the value of chi-square (column 2), degrees of freedom (column 3) and $p$-value (column 4), respectively. The last row reports the joint statistics of the four variables excluded from the equation. The first part of the table describes the result to examine whether one should exclude each variable out of the equation of LNPOV. Similarly, each following tables reports the results for the equation of LNGDP, LNUNE, LNTOU and LNCPI, respectively. The test suggests that the four variables GDP, UNE, TOU and CPI are not exogenous, since the $p$ values of the joint test for each equation are $0.085,0.023,0.000$ and 0.011 , respectively except for POV with a $p$-value of 0.721 . The results show that the null hypothesis of excluding GDP and TOU from the POV equation cannot be rejected at $1 \%$ level of significance, since the values of the chi-square are 2.807 and 2.148, and their $p$-values are 0.591 and 0.709 respectively. These suggest that GDP does not cause POV, and TOU does not cause POV. The unidirectional causality occurs among these variables which are POV on GDP, CPI on POV, POV on TOU, GDP on UNE, GDP on TOU and CPI on TOU. This test also proves bidirectional causality occurs only between POV and UNE. All these causalities are significant at $5 \%$ level of significance. One setback of this test is that it does not indicate the relationship between the variables for example whether GDP and UNE have a positive or negative effect on POV as well as to determine their relative strength between the variables.

\section{Conclusion and Recommendations}

This paper applies the Johansen Co-integration test to examine the long run equilibrium relationship between the macroeconomic factors i.e. Gross domestic product per capita (GDP), unemployment (UNE), tourist receipts (TOU), consumer price index (CPI) and poverty rate (POV) in Malaysia from 1969-2014. The cointegration test indicates that five variables are co-integrated and have a long run relationship. The Granger causality test indicated a significant unidirectional causality between POV on GDP, CPI on POV and POV on TOU. There is also evidence that the two-way causalities occur between POV and UNE. The findings show that poverty is the key concern to promote economic growth, tourism and employment. The findings are consistent with the policies implemented in Malaysia. The government's pro-active strategies formulated in the "Five-Year" Malaysia Plans have not only successfully reduced poverty over the year from $49.3 \%$ in 1970 to $1 \%$ in 2013 but has also generated robust economic growth alongside promoting tourism and creating employment.

However, policy-makers need to be mindful of the existing hard-core poor and the vulnerable group with respect to spatial and community variation. New categories of poverty are emerging from globalization consisting of foreign migrant workers and urbanization that is the rural-urban migration in search for job opportunities. Besides this, the issue of an aging population is surfacing, as by the year 2020 the number of 
Malaysian above 60 years will reach 3.25 million an increase of $210 \%$ from the year 1990 (Mafauzy, 2000) and are vulnerable to poverty as their employment opportunities are limited (Masud \& Haron, 2014). As mentioned by Nair \& Sagaran (2015) comprehensive policies which are dynamic that pulls the poor out of their doldrums and integrate with the modern sector to move up the value chain are needed to address poverty. Addressing the various aspects of poverty by formulating inclusive policy is the key challenge for Malaysia to achieve high-income status by the year 2020. There are various methods to examine this linkage. This study uses cointegration analysis to determine the long-run relationship and Granger causality to examine the direction of the relationship between poverty and selected macroeconomic variables. For future studies to explore this linkage it is recommended to use headcount ratio for poverty and Gini coefficient.

Acknowledgment: We highly appreciate the financial grants received from RMI and the Faculty of Business and Management, University Technology MARA.

\section{References}

Affandi, A. \& Astuti, D. P. (2014). Dynamic model of Ibn Khaldun theory on poverty. Humanomics, 30(2), 136161.

Afzal, M., Malik, M. E., Begum, I., Sarwar, K. \& Fatima, H. (2012). Relationship among Education, Poverty and Economic Growth in Pakistan: An Econometric Analysis. Journal of Elementary Education, 22(1), 2345.

Ahmed, E. A. (2014). Economic Aspects and Applied Policies of Poverty Reduction in Malaysia. Journal of Scientific Research \& Reports, 3(22).

Akhtar, M. N., Hunjra, A. I., Safwan, N. \& Ahmad, A. (2012). Longrun Relationship Between Poverty And Macroeconomic Variables In Pakistan. Actual Problems of Economics, 2(4).

Akinbobola, T. O. \& Saibu, M. O. O. (2004). Income Inequality, Unemployment, and Poverty in Nigeria: A Vector Autoregressive Approach. Journal of Policy Reform, 7(3), 175-183.

Amini, C. \& Dal Bianco, S. (2016). Poverty, Growth. Inequality and Propoor Factors: New Evidence from Macro Data. Journal of Developing Areas, 5(2), 231-254.

Ang, J. B. (2008). Economic development, pollutant emissions and energy consumption in Malaysia. Journal of Policy Modelling, 30(2), 271-278.

Ashley, C. \& Mitchell, J. (2007). Assessing how tourism revenues reach the poor (ODI Briefing Paper No. 21). London: Overseas Development Institute.

Belke, A. \& Wernet, A. (2015). Poverty Reduction through Growth and Redistribution Policies-a Panel Analysis for 59 Developing Countries. Review of Development Economics, 19(1), 143-162.

Budget 2017. (2016, November 06). Retrieved from: http://www.bajet.com.my/najib-presenting-budget$2017 /$

Carbone, M. (2005). Sustainable Tourism in Developing Countries: Poverty alleviation, participatory planning and ethical issues. The European Journal of Development Research, 17(3), 559-65.

Chani, M. I., Pervaiz, Z., Jan, S. A., Ali, A. \& Chaudhary, A. R. (2011). Poverty, Inflation and Economic Growth: Empirical Evidence from Pakistan. World Applied Sciences Journal, 14(7), 1058-1063.

Croes, R. (2014). Tourism and Poverty reduction in Latin America: Where does the region stand? Worldwide Hospitality and Tourism, 6(3) 293-300.

Croes, R. \& Vanegas Sr, M. (2008). Cointegration and Causality between Tourism and Poverty Reduction. [Article]. Journal of Travel Research, 47(1), 94-103.

Defina, R. H. (2002). Does Lower Unemployment Reduce Poverty? Federal Reserve Bank of Philadelphia Business Review, 2, 34-41.

Defina, R. H. \& Thanawala, K. (2009). The Impact of Unemployment and Inequality on Poverty in Canada. Indian Journal of Economics and Business, 1, 17-26.

Easterly, W. \& Fischer, S. (2001). Inflation and the Poor. Journal of Money, Credit, and Banking, 33(2), 160-178.

Gascón, J. (2014). Pro-Poor Tourism as a Strategy to Fight Rural Poverty: A Critique. [Article]. Journal of Agrarian Change, 15(4), 499-518.

Hatta, Z. A. \& Ali, I. (2013). Poverty Reduction Policies in Malaysia: Trends, Strategies and Challenges. Asian Culture and History, 5(2).

Iceland, J. (2005). Measuring Poverty: Theoretical and Empirical Considerations. Measurement: Interdisciplinary Reseach \& Perspective, 3, 199-235. 
Jala, I. (2015). The Measurement of Poverty Transformation. Retrieve from: http://etp.pemandu.gov.my/Transformation_Unplugged-@-The_measure_of_poverty.aspx

Kashi, F. K. \& Tash, M. N. S. (2014). Effects of Macroeconomic Variables on Poverty in Iran (Application of Bootstrap Technique). Theoretical and Applied Economics, 21(5), 85-96.

Kakwani, N. \& Pernia, E. M. (2000). What Is Pro-poor Growth? Asian Development Review, 18(1), 1-16.

Mafauzy, M. (2000). The Problems and Challenges of the Aging Population of Malaysia. The Malaysian Journal of Medical Sciences, 7(1), 1-3.

Masud, J. \& Haron, S. A. (2014). Income Disparity among Older Malaysians. Research in Applied Economics 6(2), 119-131.

Nair, S. \& Sagaran, S. (2015). Poverty in Malaysia: Need for a Paradigm Shift. Institutions and Economic, 7(1), 95-123

Nations, U. (2015). Millennium Development Goals Report 2015:Malaysia. Retrieved from http://www.un.org/millenniumgoals/

Nguyen, H. T. (2011). Exports, Imports, FDI and Economic Growth. Discussion Papers in Economics. Working Paper No. 11-03. University of Colorado at Boulder, Boulder, Colorado.

Page, J. \& Shimeles, A. (2015). Aid, Employment and Poverty Reduction in Africa. African Development Review/Revue Africaine de Developpement, 27, 17-30.

Powers, E. T. (1995). Inflation, unemployment, and poverty revisited. [Article]. Economic Review, 3, 2-1

Ravallion, M. (1997). Can High-Inequality Developing Countries Escape Absolute Poverty? EconomicLetters, $56,51-57$.

Saayman, M., Rossouw, R. \& Krugell, W. (2012). The impact of tourism on poverty in South Africa. Development Southern Africa, 29(3), 462-487.

Sabir, D. H. M. \& Tahir, S. H. (2012). The Impact of Different Macroeconomic Variables on Poverty in Pakistan. Interdisciplinary Journal of Contemporary Research In Business, 3(10), 488-799.

Son, H. H. \& Kakwani, N. (2008). Measuring the Impact of Price Changes on Poverty. Journal of Economic Inequality, 7(4), 395-410.

Tahir, S. H., Perveen, N., Ismail, A. \& Sabir, H. M. (2014). Impact of GDP Growth Rate on Poverty of Pakistan: A quantitative Approach. Euro-Asian Journal of Economics and Finance, 2(2), 119-126.

Tyler, G. L., El-Ghonemy, R. \& Couvreur, Y. (1993). Alleviating Rural Poverty Through Agricultural Growth. The Journal of Development Studies, 29(2), 358-364.

Vanegas, M. (2014). The Triangle of Poverty, Economic Growth, and Inequality in Central America: does tourism matter? Worldwide Hospitality and Tourism, 6(3), 277-292.

Vijayakumar, S. (2013). An Empirical Study on the Nexus of Poverty, GDP Growth, Dependency Ratio and Employment in Developing Countries. Journal of Competitiveness, 5(2), 67-82.

WTTC. (2014). Travel \& Torism Economic Impact 2014: World Travel and Tourism Council.

WTO. (2002). Tourism and Poverty Alleviation. Madrid: World Tourism Organisation

Zainal, N. R., Kaur, G., Ahmad, N. A. \& Khalili, J. M. (2012). Housing Conditions and Quality of Life of the Urban Poor in Malaysia. Procedia - Social and Behavioral Sciences, 50(0), 827-838. 